\title{
PENDIDIKAN KARAKTER SEPENUH HATI PADA SISWA MADRASAH IBTIDAIYAH
}

\author{
Mahmud Syukri', Muhammad Saleh ${ }^{2}$, Farid Ma'ruf $^{3}$ \\ STAI KH. Abdul Kabier \\ ukiubaid@gmail.com ${ }^{1}$, muhamadsaleh024@gmail.com², faridmr12@gmail.com³
}

\begin{abstract}
It is very important for schools that educate children by making educational innovations to maximize the inculcation of character in them. This is inseparable from the challenges of technological development and globalization which easily influences children to commit social deviations. Wholehearted education as an alternative solution for dedication to elementary school children. Learn from madrasas ibtidaiyah how to instill the value of character in order to form a strong and steadfast person with his principles through a wholehearted educational process.
\end{abstract}

Keyword: Education Model, Wholehearted, Islamic elementaris school

\begin{abstract}
ABSTRAK
Penting sekali bagi sekolah yang mendidik anak-anak dengan melakukan inovasi pendidikan untuk memaksimalkan penanaman karakter kepadanya. Hal ini tidak terlepas dari tantangan perkembangan teknologi dan globalisasi yang mudah sekali mempengaruhi anak untuk melakukan penyimpangan sosial. Pendidikan sepenuh hati sebagai alternative solusi untuk melakukan dedikasi kepada anak sekolah dasar. Belajar dari madrasah ibtidaiyah bagaimana menanamkan nilai karakter agar terbentuk pribadi yang kuat dan teguh dengan prinsipnya melalui proses pendidikan sepenuh hati.
\end{abstract}

Kata kunci: Model Pendidikan, Karakter sepenuh hati, Madrasah Ibtidaiyah 


\section{PENDAHULUAN}

Salah satu data yang mengkhawatirkan bagi anak-anak yakni peristiwa penyimpangan social di kota-kota besar salah satunya Serang. Daerah yang dikenal dengan sebutan kota pendidikan masih saja memiliki peluang penyimpangan sosial khususnya pada anak-anak. Hal ini ini terjadi pada Sekolah Dasar di Kabupaten Serang dimana kasus tentang pengisapan vape yang dilakukan secara bersamaan. Perilaku tersebut dilakukan atas pengaruh anak kelas VI sebagai otak kejahatan perilaku pengisapan vape yang meraciknya atas pengaruh anak punk yang dikenalnya di media sosial. Sehingga guru melakukan pelaporan pada polsek terdekat yang disertai dengan pemanggilan orang tua anak pengisap vape sehingga diperoleh informasi sebagaimana diatas bahwa anak yang lain ikutikutan sedangkan peraciknya anak kelas VI yang diajari anak punk (kabarbanten.com).

Oleh karena itu wajar sekali bilamana pemerintah memprioritaskan penguatan karakter yang harus dilakukan kepada anak-anak melalui Program pendidikan karakter di Indonesia berdasarkan Peraturan Presiden No. 87 tahun 2017 yakni Penguatan Pendidikan Karakter (PPK) sebagai bagian dari Nawa Cita Jokowidodo yang tertuang dalam poin kedelapan sebagai bagian dari program revolusi mental. Mengapa pendidikan karakter di Indonesia dianggap penting? Sehingga sampai menjadi icon revolusi mental pemerintahan presiden ketujuh.

Program penguatan pendidikan karakter dapat diimplementasikan melalui pendidikan sepenuh hati pada siswa Madrasah Ibtidaiyah atau sejenisnya. Hal ini penting untuk membangun karakter siswa agar terbentuk secara utuh tanpa sedikitpun celah untuk melakukan penyimpangan sosial karena setiap aktifitas mulai lisan hingga gerakan berlandaskan hati nurani yang bersih. Dengan demikian jurnal ini akan menguraikan model pendidikan karakter berbasis sepenuh hati agar bisa diterapkan pada anak-anak.

\section{METODE}

Paradigma penelitian yang digunakan adalah postpositivisme. Artinya usaha mendeskripsikan fenomena berdasarkan data dan fakta. Metode penelitian yang digunakan adalah kualitatif. Sementara pendekatan yang digunakan adalah kualitatif deskriptif. Dalam pandangan (Creswell, 2010: 4) penelitian kualitatif didefinisikan dengan metode untuk mengungkap dan memahami makna problem sosial atau kemanusiaan yang dilakukan individu atau kelompok. Sementara jenis penelitian yang digunakan adalah studi pustaka (library research). Jenis penelitian ini berusaha melacak data berdasarkan buku/referensi/literatur sejenisnya yang relevan dengan permasalahan atau tema penelitian serta menjadikannya sebagai objek utama (Hadi, 1995: 3). Dengan demikian, data utama diperoleh berdasarkan literature penelitian.

\section{HASIL DAN PEMBAHASAN}

Pendidikan sepenuh hati adalah usaha sadara dan terencana untuk membangun kepekaan hati peserta didik terhadap lingkungan sekitarnya. Proses ini penting dilakukan dalam meningkatkan kualitas proses pembentukan karakter anak-anak. Pada masa tersebut, siswa lebih senang menerima pengetahuan dibandingkan mendialogkan atau menganalisisnya. Sehingga proses pembentukan katrakter lebih mudah dilakukan. Karakter melekat dalam diri manusia sebagai manifestasi hati nurani menjadi identitas kepribadiannya. Hati yang bersih akan membentuk karakter dan kepribadian baik. 
Dalam penelitian ini ditemukan model pendidikan karakter sepenuh hati yang dapat dilakukan pada siswa Madrasah Ibtidaiyah. Hati nurani dapat bergerak melakukan bilamana tumbuh rasa peka terhadap lingkungan dan kondisi disekitarnya. Hal ini tentu sangat berkaitan dengan aspek afketif yang didefiniskan dengan effect atau perasaan. Model pendidikan karakter sepenuh hati selaras dengan pendidikan afektif. Menurut Muhaimin (2002) Pendekatan model pembelajaran afektif dalam PAI terdiri atas 6 macam diantaranya: pembiasaan, pengalaman, emosional, rasional, fungsional dan keteladanan. Adapun penjelasan pendekatan pembelajaran afektif diatas sebagai berikut:

\section{Pendekatan Pengalaman}

Pendekatan pengalaman adalah pendekatan yang mengajarkan peserta didik untuk merasakan atau mengalami atas materi pelajaran keagamaan yang telah diberikan. Dalam (Brookfield, 1983: 63) pendekatan belajar melalui pengalaman dibagi menjadi dua macam diantaranya: pertama, pembelajaran yang bertumpu pada materi dan implementasi keilmuan yang telah dipelajari, tidak hanya berfikir namun melaksanakan (L. Borzak, 1981: 9). Kedua, (C. Houle, 1980: 221) pembelajaran yang berdasar pada seluruh pengalaman hidupnya dalam berbagai kegiatan.

Sementara Carl Rogers dalam (Hussain Othman, 2008: 108) melakukan identifikasi ciri pembelajaran pengalaman terdiri atas: kehendak kendiri (selfinitiated), keterlibatan secara peribadi (personal involvement), evaluasi sendiri (evaluated by learner) dan memberikan kesan menyeluruh kepada pelajar (pervasive effects on learner).

\section{Pendekatan Pembiasaan}

Pendekatan pembiasaan merupakan pendekatan yang diberikan kepada peserta didik dengan selalu memberikan kesempatan agar senantiasa mengamalkan akhlakul karimah dan ajaran agama (Muhaimin, 2002: 174). Pendekatan pembiasaan memiliki hubungan dengan teori belajar behavioristik Ivan Pavlov dengan teorinya Cassical Conditioning (pembiasaan klasik). Dalam proses pembelajarannya pendapat Skinner (Muhibbin S., 2009: 97) tentang tepori Ivan Pavlov dengan mengacu kepada dua prinsip yakni law of respondent conditioning (hukum pembiasaan yang dituntut) dan law of respondent extinction (hukum pemusnahan yang dituntut).

Ragam belajar menggunakan pendekatan kebiasaan merupakan usaha membiasakan atau menyempurnakan bahkan memperbaiki yang sudah ada. Banyak cara yang dapat dilakukan dalam penggunaan pendekatan ini. Mayoritas melalui penggunaan keteladanan, perintah dan pengalaman khusus. Selain itu juga dituntut menggunakan perintah dan hukuman. Tujuannya yakni agar siswa bertanggungjawab terhadap tugas yang dilakukan serta terbiasa melakukan perbuatan baru yang lebih tepat dan seirama dengan konteks kehidupannya (Muhibbin S., 2009: 128).

Pembiasaan seharusnya diberikan sejak usia dini termasuk pada anak madrasah ibtidaiyah. Rasionalisasinya pada fase tersebut kondisi kepribadiannya belum matang, namun ingatannya sangat kuat. Sehingga pada fase inilah dapat dibiasakan melakukan amal baik agar terbiasa dan mengingatnya sampai mengakar serta larut dalam memori dan kepribadiannya. Pada akhirnya tanpa disadari anak terbiasa melakukan tanpa diminta. Pendekatan ini sangat efektif digunakan untuk mengawali proses pendidikan dalam menanamkan nilai moral ke dalam jiwa anak. Selanjutnya 
nilai tersebut dapat termanifestasi dalam kehidupan selanjutnya melangkah usia remaja hingga dewasa (A. Arief, 2002: 110).

\section{Pendekatan Emosional}

Pendekatan emosional, merupakan usaha untuk menggugah emosi dan perasaan peserta didik dalam memahami, meyakini, dan menghayati akidah Islam serta memotivasinys agar ikhlas menerapkan ajaran agamanya terlebih yang berkaitan dengan akhlakul karimah (Muhaimin, 2002: 174). Emosi merupakan gejala kejiwaan yang berhubungan dengan masalah perasaan dan terdapat dalam diri seseorang. Adapun perasaan yang dimiliki oleh setiap orang dibagi menjadi dua yakni perasaan jasmani yang disebut dengan perasaan tingkat rendah dan perasaan rohani yang disebut dengan perasaan tingkat tinggi.

Adapun perasaan jasmani meliputi: perasaan indrawi, naluri dan vital. Sedangkan perasaan rohani (Baharuddin, 2012: 146-147) meliputi: intelektual, estetis (keindahan), etis (susila), sosial (kemasyarakatan), harga diri, dan ketuhanan (religius). Penjelasan macam-macam perasaan tingkat rendah sebagai berikut (Baharuddin, 2012: 147):

a. Perasaan indrawi sebagai perasaan yang timbul atas benturan atas lingkungan sekitar dengan indra manusia seperti: asam, asin, pahit, manis, dan lain sebagainya.

b. Perasaan naluri merupakan perasaan yang muncul atas dorongan orang lain kepada individu misalnya marah, takut, dorongan seksual perasaan bosan dan lain sebagainya

c. Perasaan vital merupakan perasaan yang muncul dari alam bawah sadar manusia atas kondisi tubuh individu misalnya haus, lapar, sakit, lelah, kenyang dan lain sebagainya.

\section{Pendekatan Rasional}

Dalam bahasa inggris, rasio berasal dari kata ratio yang artinya adalah nalar pikir dan akal sehat. Selanjutnya istilah rasio (KBBI, 2005: 933) dinalarkan dalam kata rasional yang memiliki arti pertimbangan logis berdasarkan pikiran sehat dan masuk akal (sesuai dengan akal).

Kedudukan manusia diantara makhluk hidup ciptaan Allah memiliki derajat tertinggi. Alasannya karena manusia mimiliki pikiran dan jiwa yang rasional. Rasionalitas diperoleh berdasarkan proses berifikir yang dipengaruhi rasio dan daya pikir walaupun keduanya (rasio dan daya pipir) memiliki fungsi yang berbeda. Kekuatan rasionalitas manusia memiliki kemampuan berfikir secara sistematis karena mampu menganalisa dan menghubungkan pengetahuan satu dengan yang lain.

Dengan demikian, dapat diketahui bersama, pendekatan rasional merupakan pendekatan yang digunakan untuk menelusuri hakikat kebenaran materi pelajaran yang disampaikan guru. Bilamana dikaitkan dengan pembelajaran PAI, pendekatan rasional bertujuan menelisik kebesaran dan kekuasaan Allah dengan penggunaan rasio (akal) secara maksimal agar siswa dapat menerima kebenaran ajaran Allah (Muhaimin, 2002: 174).

Operasional penggunaan pendekatan rasional dalam pembelajaran adalah memberikan pemahaman secara benar dan tepat terhadap perbuatan yang akan dilakasanakan oleh siswa. Contohnya, kemampuan guru menguraikan materi pelajaran secara menarik serta mudah dicerna akal siswa dengan penggunaan ceramah. Ceramah tersebut akan mudah dijangkau oleh 
akal, bilamana penyajian dalam materi pelajaran menarik didengarkan dan dicerna siswa.

Pendekatan rasional memiliki kemampuan untuk membangun prinsip dalam diri siswa. Alasannya, pendekatan ini menghindarkan siswa dari sikap ikut-ikutan serta menuntun peserta didik mengerjakan perbuatan baik berdasarkan argumentasi kuat dalam rasionalitasnya (A. Nata, 2012, 168169). Argumentasi kuat pada rasionalitas siswa tertanam mengakar dan berdampak pada teguh pendirian dan kesadaran tinggi untuk melaksanakan amaliyah kebaiakan dalam kehidupannya.

Indikator rasionalitas keberagamaan manusia bisa diukur dengan seberapa besar pemakaian akal dalam memahami serta mengamalkan ajaran agama (Achmadi, 2010: 204). Anjuran penggunaan akal untuk memahami dan mengamlkan ajaran agama sangatlah dianjurkan dalam Islam. Pendapat tersebut diperkuat oleh Abdurrahman An-Nahlawi yang berpendapat bahwa Allah mendidik akal manusia melalui penyajian firman Allah dalam AlQur'an supaya memilki pemikiran yang argumentatif, pengetahuan yang baik, penalaran ilmiah dan pnggunaan metode eksperimental (Nahlawi, 2002: 81$82)$.

Selanjutnya, rasionalitas mampu menghasilkan keseimbangan dalam kehidupan. Faktanya terdapat tiga poin untuk menghasilkan keseimbangan dan akal menempati posisi salah satu diatara ketiga poin, yakni penggunaan logika berfikir yang baik akan menghasilkan ilmu pengetahuan, penggunaan etika baik, mewujudkan akhlak mulia, dan mengembangkan nilai estetika, melahirkan seni dan keindahan (A. Nata, 2009: 113).

Kemampuan mengoptimalkan fungsi indrawi dan rasio sebagai salah satu karakteristik rasio. Keberhasilan mentrasformasikan beragam potensi dengan mengoptimalkan kedua fungsi indrawi dan rasio berdampak pada usaha mengungkap realitas pengetahuan di sekelilingnya serta mengabstraksikannya. Dengan demikian seseorang memiliki pemahaman dan pengetahuan berdasarkan kebenaran yang mutlak (Mahmud A., 2008: 118). Perlu digaris bawahi, fungsi rasio tidak sekedar mengetahui sesuatu, akan tetapi rasio berfungsi memutuskan baik dan buruknya sesuatu atau benar dan salahnya sesuatu (Mahmud A., 2008: 120).

\section{Pendekatan Fungsional}

Pendekatan fungsional, menyampaikan materi agama Islam dari sisi manfaat dalam kehidupan sehari-hari yang disesuaikan dengan tingkat perkembangan peserta didik (Muhaimin, 2002: 174). Pendekatan fungsional merupakan pendekatan yang dilandaskan pada asumsi bahwa semua ilmu pengetahuan di diajarkan selain memiliki nilai akademisi juga memiliki nilai praktis selain (A. Nata, 2009: 169).

\section{Pendekatan Keteladanan}

Pendekatan keteladanan, menjadikan seluruh stakeholeders di lingkungan sekolah sebagai center of modelling baik secara langsung maupun tidak langsung dengan tujuan terciptanya lingkungan yang terdidik (Muhaimin, 2002: 174). Pendekatan keteladanan merupakan pendekatan pembelajaran berdasarkan pada model perilaku yang dipertontonkan pendidik, karyawan, orang tua dan masyarakat kepada siswa. Dapat ditarik kesimpulan bahwa, keteladanan sifatnya sensitif karena menjadi kaca peserta didik dalam berucap, bersikap maupun berbuat sehingga guru menjadi kaca suri tauladan baik peserta didik (Fadillah, 2012: 167). 
Keberhasilan penggunaan pendekatan keteladanan dalam pembelajaran afeksi dapat dipertanggung jawabkan. Alasannya suri tauladan yang baik dalam perspektif anak adalah lingkungan pendidikan karena didalamnya terdapat nilai-nilai baik seperti sopan santun, senyum, salam dan sapa sehingga semua nilai yang ada dapat diimitasi dalam kehidupannya. Pendekatan keteladanan paling meyakinkan membentuk atau mempersiapkan moralitas spritual dan sosial siswa. Selain itu, menanamkan nilai moral dan sosial sangat efektif menggunakan pendekatan modelling (Fadillah, 2012: 166)g. Oleh karena itu, pendekatan keteladana dapat disebut sebagai pendekatan influitif.

Penggunaan pendekatan keteladanan hendaknya dimulai sejak anak masuk pendidikan usia dini. Alasannya pada usia dini karakteristik maupun keunikan seorang anak suka meniru sebagaimana teorinya piaget anak usia dini masuk dalam tahapan pra operasional pada usia kisaran 2-7 tahun. Berdasar pada alasan diatas, mengawali pendidikan pada anak usia dini pendidikan haruslah berdasarkan pada suri tauladan baik dan kemudian menunjukkanya kepada peserta didik agar mereka menirunya. Tauladan baik inilah memiliki relevansi dengan pendidikan anak usia dini, dimana cerminan perilaku peserta didik adalah pendidiknya sendiri.

Adapun penerapan pendekatan keteladanan di sekolah, terdapat beberapa hal yang perlu diperhatikan untuk digunakan dalam pembelajaran (Fadillah, 2012: 168):

1) Guru memperlihtakan sesuatu yang memiliki nilai teladan baik kepada siswa utamnya perilaku guru sendiri

2) Proses pembelajaran dengan menggunakan pendekatan keteladanan dapat memertontonkan atau menceritakan kisah nabi, sahabat dan tokoh muslim Indonesia dan dunia yang pada intinya cerita tersebut mengandung akhlak mulia.

3) Pendekatan keteladanaan bisa diterapkan dengan memperlihatkan kepada anak guru yang sedang memberikan makan atau guru yang sedangn mengulurkan tangan kepada orang yang kurang tercukupi seperti pengemis, fakir dan miskin.

Selain memperlihatkan kepada anak guru dapat mengajaknya untuk praktik melakukan perbuatan tersebut. Kegiatan seperti ini tidaklah harus dilakukan di sekolah, akan tetapi ditindak lanjuti oleh orang tua di rumah masing-masing. Selain pendekatan, juga terdapat metode yang dapat digunakan dalam pendidikan karakter sepenuh hati. Adapun metode ini juga berlandasakan aspek afektif siswa. Beragam pendekatan yang telah dijabarkan diatas selanjutnya dijabarkan dalam bentuk metode pembelajaran PAI yang memiliki orientasi pada nilai afektif. Tentunya memiliki keterkaitan dengan pendidikan karakter sepenuh hati. Terdapat empat metode pembelajaran yang bisa digunakan diantaranya metode dogmatik, metode deduktif, metode induktif dan metode reflektif (Muhaimin, 2002: 174).

Adapun penjelasan mengenai keempat metode pembelajaran tersebut, akan dijelaskan sebagai berikut:

1. Metode dogmatik merupakan cara membelajarkan peserta didik dengan menguraikan nilai baik dan buruk, benar maupun salah tanpa mempertanyakan alasan dibalik nilai yang diberikannya. Peserta didik menerima penjelasan pendidik secara lapang dada (Muhaimin, 2002: 174). Pengunaan metode ini memang berdampak pada pengendapan rasionalitas 
peserta didik. Dampaknya pemahaman yang diperolehnya hanya sampai pada tahapan penerapan atas dasar pemahamnnya dan belum sampai pada tahapan kesadaran yang timbul dari hati peserta didik sendiri.

2. Metode deduktif, merupakan cara membelajarkan siswa dengan menguraikan nilai kebenaran tentang ketuhanan dan kemanusiaan yang memiliki nilai baik berdasarkan kajian teoritis yang selanjutnya diasosiasikan dengan realita kehidupan sehari-hari yang relevan dengan nilai kebenaran yang disampaikan pada siswa (Muhaimin, 2002: 175). Kelebihan metode ini terutama pada siswa pemula adalah menguatkan peserta didik untuk meyakini konsep kebenaran ajaran Allah dan ajarannya yang memiliki nilai baik. Bagaimana tidak, karena kajian teoritis di relavansikan dengan kasus nyata dan fakta, sehingga pemahaman nilai kebenaran tentnag ajaran Allah akan tertanam kuat dalam jiwa siswa karena diperlihatkan contoh nyata dalam kehidupan.

3. Metode induktif, merupakan cara membelajarkan siswa dengan menguraikan detail kasus atau peritiwa yang memiliki nilai baik maupun buruk yang selanjutnya direlevansikan dengan kajian teori kedua nilai tersebut (Muhaimin, 2002: 175). Kelebihan metode ini sama dengan kelebihan metode induktif diatas, hanya saja letak perbedaannya siswa memiliki gaya berfikir kritis dan solutif karena dituntut untuk mencari solusi atas permasalahan nyata dengan membentuk kesimpulan abstrak berdasarkan kajian teoritis. Kajian teoritis yang bersinggungan dengan kasus yang disajikan kepada siswa haruslah ada. Karena kajian teoritis inilah yang mampu menguatkan analisa kasus berdasarkan pemikiran siswa dalam mencari nilai kebenaran dan kebaikan yang terkandung di dalamnya.

4. Metode reflektif, merupakan korelasi metode deduktif dan induktif dengan cara menyajikan teoritis suatu nilai baik dan benar kemudian dikoerlasikan dengan peristiwa nyata nilai baik dan benar dan kemudian dikembalikan pada kajian teoritis nilai kebaikan dan kebenaran (Muhaimin, 2002: 175). Penggunaan metode ini dapat menutupi kelemahan metode deduktif yang terkadang hasilnya kurang empiris serta metode induktif yang terkadang hasilnya bastrak atau tidak konsisten.

\section{KESIMPULAN}

Model pendidikan karakter sepenuh hati merupakan kerangka konsemtual pendidikan berdasarkan surat An-Nisa' ayat 9. Model pendidikan ini menyentuh aspek perasaan siswa agar peka terhadap ilmu yang telah diajarkannya untuk dimanifestasi dalam kehidupan sehari-hari. Beberapa pendekatan yang dapat digunakan dalam pendidikan sepenuh hati dianatarnya: pembiasaan, pengalaman, emosional, rasional, fungsional dan keteladanan. Sementara metode yang dapat digunakan meliputi: dogmatik, deduktif, induktif dan reflektif. 


\section{DAFTAR RUJUKAN}

Achmadi. 2010. Ideologi Pendidikan Islam: Paradigma Humanisme teosentris. Yogyakarta:

Pustaka Pelajar

An-Nahlawi, Abdurrahman. 2002. Pendidikan Islam di Rumah, Sekolah dan Masyarakat.Jakarta:

Gema Insani Press Arief, Armai. 2002. Pengantar Ilmu dan Metodologi PendidikanIslam.Jakarta: Ciputat Pers

Arif, Mahmud. 2008. Pendidikan Islam Transformatif. Yogyakarta: Lkis

Baharuddin. 2012. Psikologi Belajar. Jogjakarta: Ar-Ruzz Media

Borzak, L. ed. 1981. Field Study. A source book for experiential learning. Beverley Hills: Sage

Publications

Brookfield, S. D. 1983. Adult Learning, Adult Education and the Community. Milton Keynes:

Open University Press

Fadlillah, Muhammad. 2012. Desain Pembelajaran PAUD: Tinjauan Teoritik dan praktik. Jogjakarta: Ar-ruzz Media

Houle, C. 1980. Continuing Learning in the Professions. San Francisco: JosseyBass http://radaranten.com/2019/09/13/miris-sejumlah-siswa-sd-diserangisap-vape-di

sekolah-ini-tindakan-polisi diakses pada tanggal 23 Maret 2019, pukul 09:38 WIB

Muhaimin. 2002. Paradigma Pendidikan Islam Upaya Mengefektifkan Pendidikan Agama Islam

di Sekolah. Bandung: PT Remaja Rosda Karya

Nata, Abuddin. 2009. Perspektif Islam Tentang Strategi Pembelajaran. Jakarta: Kencana

Nata, Abuddin. 2009. Ilmu Pendidikan Islam dengan Pendekatan Multidisipliner. Jakarta: Raja

Grafindo Persada

Othman, Hussain. 2008. Perlaksanaan Pendekatan Pembelajaran Berasaskan Pengalaman

(Pbl Dan Popbl) Bagi Meningkatkan Kemahiran Insaniah Pelajar. Prosiding SKIKS

Syah, Muhibbin. 2009. Psikologi Belajar. Jakarta: Rajawali Pers

Tim Penyusun Kamus Pusat Pembinaan dan Pengembangan Bahasa. 2005. Kamus Besar Bahasa

Indonesia. Jakarta: Balai Pustaka 